\title{
Correction to: The Changing Landscape of Lymphoma Associated with HIV Infection
}

\author{
Kai Hübel ${ }^{1}$
}

Published online: 9 August 2021

(C) The Authors 2021

\section{Correction to: Current Oncology Reports (2020) 22: 111 https://doi.org/10.1007/s11912-020-00973-0}

The article "The Changing Landscape of Lymphoma Associated with HIV Infection," written by Kai Hübel, was originally published Online First without Open Access. After publication in volume 22, issue 11, page 81-90, the author decided to opt for Open Choice and to make the article an Open Access publication. Therefore, the copyright of the article has been changed to (c) The Author(s) 2021, and the article is forthwith distributed under the terms of the Creative Commons Attribution 4.0 International License, which permits use, sharing, adaptation, distribution and reproduction in any medium or format, as long as you give appropriate credit to the original author(s) and the source, provide a link to the Creative Commons license, and indicate if changes were made. The images or other third party material in this article is included in the article's Creative Commons license, unless indicated otherwise in a credit line to the material. If the material is not included in the article's Creative Commons license and your intended use is not permitted by statutory regulation or exceeds the permitted use, you will need to obtain permission directly from the copyright holder. To view a copy of this license, visit http:// creativecommons.org/licenses/by/4.0. Open Access funding was enabled and organized by Projekt DEAL.

The original article has been corrected.

Publisher's Note Springer Nature remains neutral with regard to jurisdictional claims in published maps and institutional affiliations.

The online version of the original article can be found at https://doi.org/ $10.1007 / \mathrm{s} 11912-020-00973-0$

Kai Hübel

kai.huebel@uni-koeln.de

1 Faculty of Medicine and University Hospital of Cologne,

Department I of Internal Medicine, University of Cologne, Kerpener Str. 62, 50937 Cologne, Germany 